\title{
Domestic Manufacturing Trends within Developing Nations Following WTO Accession
}

\author{
James J. Tanoos, ${ }^{1 *}$ \\ *l PhD Clinical Associate Professor, Purdue Polytechnic Vincennes
}

*Corresponding Author: -

\begin{abstract}
: -
The shift in the new members of the World Trade Organization from developed countries to underdeveloped countries has resulted in vastly increased access to new export markets for these underdeveloped countries. As such, the process of accession into the WTO has been increasingly coveted by underdeveloped countries, and numerous studies highlighted increased trade in the years after WTO accession for a new member. Underdeveloped WTO member countries, in particular China, have received a unprecedented scrutiny in international trade, as their overall economies have greatly benefited, prompting anti-dumping grievances from developed countries due to their massive success in the export of manufactured goods. This has changed the purview of the WTO from trade dispute resolution to trade protection. Nevertheless, the economic success accruing in China after WTO membership in 2001 has been so substantial that other countries are devoting vast resources to seeking and navigating through the accession process, provoking coinciding outcries from developed countries for a more stringent WTO accession process because of protectionist concerns about the dumping of products from underdeveloped countries into their domestic markets. This study will assess manufacturing-related GDP in developing countries after WTO accession in order to determine the validity of these recent complaints directed at the WTO.
\end{abstract}

Keywords: - Domestic, Manufacturing, Trends, Developing, Nations, Following, WTO, Accession

\section{(c) $(\$)$}




\section{INTRODUCTION}

The prestigious group of nations governing global trade, the World Trade Organization (WTO), was originally an association composed of industrialized countries. More recently, membership in this group has been coveted by underdeveloped countries wishing to utilize the group's association to gain access to export markets, particularly for their manufactured goods. Most studies of the WTO have focused on subtopics including enhancing the welfare of citizens, dispute resolution, and decreased tariffs (Huerta- Goldman, 2010; Liu, 2014). The WTO "accession" process, which is the official entrance into the WTO after successful completion of WTO-mandated negotiations and reforms, has been a focus of many countries because of the increased access to new markets and economic development that supposedly ensue after membership is approved.

As a result of more underdeveloped countries entering the WTO, dialogue associated with the WTO has shifted from trade dispute resolution to trade protection disputes such as anti-dumping measures and complaints related to environmental and human rights concerns due to the manufacturing and exporting of goods from underdeveloped countries (Zhao et. al, 2012; Cook, 2015).

It has been confirmed that countries successfully negotiating for WTO accession experience increases in trade in the years after joining. As such, this study will analyze trade patterns in a historical context to further analyze this trade to determine if successful WTO accession translates into increased manufacturing-related GDP during the years immediately thereafter.

\section{Literature Review and Background}

The predecessor to the WTO was the General Agreement on Tariffs and Trade (GATT). Both international institutions were originally designed to reduce tariff and non-tariff trade barriers for member nations. GATT and the WTO have been perceived as prestigious groups because of their members' ability to more easily sell good to new countries. More recently, underdeveloped nations wish to join the WTO as they attempt to grow their manufacturing sector and gain access to new export markets (Hoadley \& Yang, 2007; Chen, 2009; Van Biesebroeck \& Zhang, 2012). Concluded bilateral and regional Free Trade Agreements (FTA's) between governments were required to be submitted to GATT and now to the WTO (Zhang, 2007; Tosevska, 2010; Neumayer, 2013; Fora, 2014). In the period from 1948-1994, GATT received 124 notifications of Regional Trade Agreements (RTAs) and since the creation of the WTO in 1995, over 400 additional arrangements covering trade in goods or services have been submitted (WTO, 2015).

WTO membership access comes with the associated Most Favored Nation status, a coveted category for a country whereby a favorable arrangement between trading countries is guaranteed (Blustein, 2009; Narlikar et al., 2012; Fora, 2014). Developing countries are now the most aggressive in pursuing membership so that their economies may take advantage of comparatively lower wage rates as they attempt to produce and export basic goods such as plastics to industrialized countries that are home to more mature, technologically-advanced competitors. The limitations that come from not having WTO membership have even been utilized as an excuse for economic stagnation and unemployment, and as a result much time and effort are dedicated to the WTO accession process (Michalopoulos, 1998; Neumayer, 2013; Liu, 2014).

There have been numerous studies devoted to the effects of free trade. The vast majority of economists point to overall economic gains from decreasing trade barriers (Friedman, 1978; Krugman, 1997; Irwin, 2015). The World Bank (2005) noted that the elimination of trade barriers is a "central" component of domestic GDP growth. Historical studies have confirmed that GATT membership resulted in positive quantitative effects on trade for member countries in the 1950s, with lesser positive effects in the 1960s and 1980s, negative effects in the 1970s, and "unstable" effects in the 1990s (Rose, 2004). More recently, Rose (2004) found that GATT/WTO membership did not seem to have much of an impact on trade through the 1990s. However, a more recent study noted that "those who engage in the greatest amount of [WTO] accession-driven liberalization experience the greatest trade increases from WTO membership, particularly in the years right after joining" (Allee \& Scalera, 2012, p. 243).

Official individual country membership into the WTO involves an official "accession" process, whereby countries must first negotiate to become part of the group (Bagwell \& Staiger, 2011; Neumayer, 2013). Governments accede to the WTO by initially requesting membership, and the process usually takes at least several years (International Economics Study Center, 1998; Neumayer, 2013; Liu, 2014). The WTO accession process generally necessitates much time and resources from a country due to its important and nuanced nature. Pelc (2011) detailed that countries often get different deals or WTO accession terms during their accession proceedings, as the process is individualized based on unique country characteristics (Williams \& Hussain, 2008; Neumayer, 2013; Liu, 2014). Neumayer (2013, p. 669) described the WTO accession process as "demanding on applicant countries, time consuming and essentially power- rather than rule-based." Another study described the process as not only economic- focused but also a means of rooting out corruption in a country (World Trade Organization Development and Economic Research Division, 2002). There are numerous studies describing the process of China's WTO accession both before and after it became the $143^{\text {rd }}$ WTO member in 2001 (Ching \& Ching, 2003; Potter, 2004; Bhattasali, 2004; Cook, 2015).

For underdeveloped countries during the past decade, entrance into the WTO has been sought in order to enhance domestic industrial production, which is perceived to be the most important economic benefit because of the access to new export markets. Geopolitical scholars point to the importance of market access for underdeveloped countries for their overall economic development (Mountjoy, 2007; Chen, 2009). This has been very true for China. Brandt et al. (2012) found that trade liberalization, particularly after WTO membership, resulted in positive domestic productivity benefits for Chinese manufacturers because of increased access to markets. China has realized so much success in exporting goods after their WTO accession that developed countries successfully negotiated with the WTO to reach 
trade protection measures such as anti-dumping duties on select Chinese industries (Wu, 2007; Chen, 2009; Zhao et al., 2012; Neumayer, 2013; Cook, 2015). Dumping is a type of predatory pricing in which a product (usually from an underdeveloped country) is sold below cost of production (usually to a developed country), often in an effort to gain market share (Huerta-Goldman, 2010; Raslan, 2009; Cook, 2015; McGovern, 2015). Many pundits point to trade liberalization and WTO membership as having a negative effect on total domestic output for developed countries, and some political factions in industrialized countries have even rallied against WTO accession because of the increased imports from underdeveloped countries (Barfield, 2003; Hufbauer \& Schott, 2005; Autor et al., 2013).

In fact, China's entrance into the WTO is seen as the impetus for a shift in overall international trade attitudes, as the WTO has now been forced into "defensive positions" with anti-dumping complaints from various actors, most notably industrialized country governments, due to their anti-dumping grievances with underdeveloped countries such as China (Zhao et al., 2012, p. 209). Manufacturing and industrial production tend to be the areas in which developing countries can best gain economic development via trade liberalization (Akyüz, 2003; Nayyar, 2013; Cook, 2015). Meanwhile, in developed countries, trade protection has tended to be concentrated in politically sensitive areas such as labor-intensive manufacturers (World Bank, 2005; Wu, 2007). As such, this has resulted in trade retaliation and protectionist measures such as anti-dumping grievances and selective tariffs levied on goods entering a domestic market that are thought to be so low in price that domestic firms in that industry will be forced out of business. The World Bank (2015, p. 152) confirmed that "..the types of goods exported by poor countries face higher tariffs in the rich countries". It is common for governments in developed areas to strategically place tariffs on different goods from various industrial sectors in the economy.

Since the overarching goal of WTO accession for underdeveloped countries is to gain access to export markets in order to increase domestic productivity, the accession process has now become a focus of scrutiny (Chen, 2009; Dix-Carneiro, 2014). Outcries for more stringent WTO accession processes now exist in conjunction with grievances such as antidumping complaints from developed countries toward underdeveloped countries in international trade (Kim, 2010; Burakovsky et al., 2012; Dix-Carneiro, 2014). This phenomenon, along with findings of positive benefits for China after WTO membership (Brandt et al., 2012) and trade increases in the immediate years after joining the WTO (Allee \& Scalera, 2012) will be used as stimuli for analysis in this study. While literature has focused on the WTO accession process as well as effects of WTO membership on total trade, there have been no studies that measure manufacturingrelated GDP, the very economic sectors of goods prompting trade protection complaints, in the years immediately after WTO accession. This study will assess trends in domestic manufacturing output in the aftermath of successful completion of WTO accession.

\section{Data and Methodology}

Historical trends related to industrial-related GDP output associated with WTO accession provided data and a crosssectional analysis was utilized as a method to examine these data. Statistics of GDP breakdown by country up to 2013 were gathered from the United Nations statistics division (UN, 2015). "GDP/breakdown at current prices in US Dollars" was obtained for 16 select firm-level data categories from 1970-2013 in 220 nations (see Appendix A). Since WTO accession is coveted for access to markets for domestic industry, two of these categories were taken that best represented domestic industry: "Mining, Manufacturing, Utilities (ISIC C-E)" and "Manufacturing (ISIC D)."

For purposes of this study, "recent" WTO accession constitutes 2000 to the present. The official list of WTO countries and their dates of accession were taken from the WTO website (WTO, 2015). Table 1 below lists 26 countries whose accession came after 2000, along with their dates of accession. This list is out of the 161 total members of the WTO.

Table 1. WTO Accession countries since 2000 the date of Accession

\begin{tabular}{|c|}
\hline Albania: 8 September 2000 \\
\hline Armenia: 5 February 2003 \\
\hline Cabo Verde:23 July 2008 \\
\hline Cambodia:13 October 2004 \\
\hline China: 11 December 2001 \\
\hline Croatia: 30 November 2000 \\
\hline Georgia: 14 June 2000 \\
\hline Jordan: 11 April 2000 \\
\hline Lithuania: 31 May 2001 \\
\hline Moldova, Republic of: 26 July 2001 \\
\hline Montenegro: 29 April 2012 \\
\hline Nepal: 23 April 2004 \\
\hline Oman: 9 November 2000 \\
\hline Russian Federation: 22 August 2012 \\
\hline Samoa: 10 May 2012 \\
\hline Saudi Arabia, Kingdom of: 11 December 2005 \\
\hline Seychelles: 26 April 2015 \\
\hline Taipei (Chinese): 1 January 2002 \\
\hline Tajikistan: 2 March 2013 \\
\hline Tonga: 27 July 2007 \\
\hline Ukraine: 16 May 2008 \\
\hline Vanuatu: 24 August 2012 \\
\hline Viet Nam: 11 January 2007 \\
\hline Yemen: 26 June 2014 \\
\hline \\
\hline The former Yugoslav Republic of Macedonia (FYROM): 4 April 2003 \\
\hline
\end{tabular}


Since Chinese Taipei's data were not included in the UN's GDP statistics, it was taken out of the sample set, which left 25 countries remaining. Of these countries, three ascended to the WTO in 2013 or later, in which case the effects of the accession were not able to be measured and were thus taken out of the sample set (Lao People's Democratic Republic2 February 2013, Seychelles-26 April 2015, and Tajikistan- 2 March 2013), leaving 22 countries in the sample set.

The year-to-year changes in domestic GDP from the prior year were utilized as a basis for analysis, and the sum of the two categories measured, "Mining, Manufacturing, Utilities (ISIC C-E)" and "Manufacturing (ISIC D)" was the basis for comparison.

\section{Results}

The average of the year-to-year manufacturing-related GDP changes for the recent WTO countries in the five years before WTO accession were used as a means of analysis versus the average of the year-to-year changes after WTO accession. Table 1 below displays these data, showing a $108.58 \%$ increase in manufacturing-related GDP for the average of the year-to-year changes in the five years before WTO accession versus a $110.12 \%$ increase for average of the year-to-year changes after WTO accession.

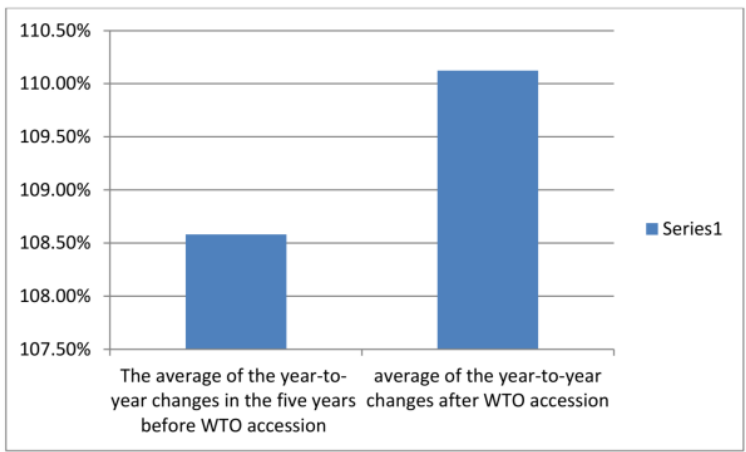

Figure 1. Average of the Year-To-Year Manufacturing-Related GDP Changes

In order to compare how these trends relate to the normal manufacturing-related GDP trends during this timeframe, data for the countries without recent WTO accession were contrasted. For those countries ascending to the WTO before 2000 as well as those countries that are not WTO members (the "field"), the year-to-year manufacturing-related GDP changes from the previous year from 2000-2013 was 104.76\%. Figure 2 displays this comparison.

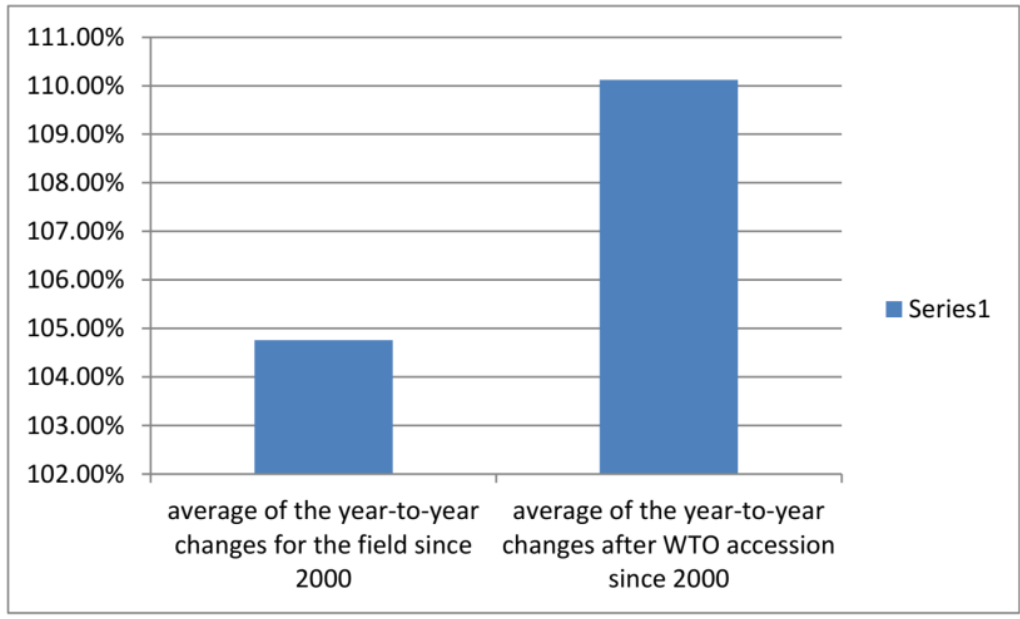

Figure 2. Average Year-To-Year Manufacturing-Related GDP Changes from the Previous Year after WTO Accession for Countries Ascending since 2000 versus the Field

\section{Reactions/Future Studies}

In the years immediately after WTO accession, there does seem to be more domestic production of manufactured goods, presumably prompted by export demands for these goods in new markets in the developed world. The statistics do seem to confirm that WTO accession is worthwhile because a country's domestic manufacturing output will rise after accession. As such, there might be some rationale for the increases in both the anti-dumping inquiries and the outcries for a more stringent accession process.

While complaints from the developed world for a more stringent accession process may accelerate, the WTO will continue to have the increased authority as arbitrator for these demands as well as for anti-dumping grievances. As an international institution, this group can and should tout the trade success of new members based on historical trends showing increased domestic output as a result of successful completion of the accession process.

Future studies might assess the direction and flow of goods from recent WTO members to ascertain where trade is being directed. Complaints about dumping and even the calls for a more stringent accession process might diminish if these 
new WTO members are exporting goods to proximate countries and/or underdeveloped countries, rather than to developed countries.

\section{References}

[1].Akyüz, Y. (2003). Developing Countries and World Trade: Performance and prospects. Penang, Malaysia: Palgrave Macmillan Press.

[2].Allee, T. \& Scalera, J. (Spring, 2012). The Divergent Effects of Joining International Organizations: Trade gains and the rigors of WTO accession. International Organization, 66(2), 243-276.

[3].Autor, D., Dorn D., \& Hanson, G. (October, 2013). The China Syndrome: Local labor market effects of import competition in the United States. The American Economic Review, 103(6), 2121-2168.

[4].Bagwell, K. \& Staiger, R. (June, 2011). What Do Trade Negotiators Negotiate About? Empirical evidence from the World Trade Organization. The American Economic Review, 101(4), 1238-1273.

[5].Barfield, C. (2003). High-tech Protectionism: The Irrationality of Antidumping Laws. Washington, DC: Aei Press. Bhattasali, D. (2004). China and the WTO: Accession, policy reform, and poverty . Washington, DC: World Bank

[6].Publications.

[7].Blustein, P. (2009). Misadventures of the Most Favored Nations: Clashing egos, inflated ambitions. New York, NY: Public Affairs Publishing.

[8].Brandt, L., Van Biesebroeck, J., Wang L., \& Zhang, Y. (October, 2012). WTO Accession and Performance of Chinese Manufacturing Firms: Industrial organization and international trade and regional economies. Centre for Economic Policy Research. Discussion Paper No. 9166.

[9].Burakovsky, I., Handrich, L., \& Hoffmann, L. (2012). Ukraine's WTO Accession: Challenge for domestic economic reforms. Heidelberg, Germany: Physica-Verlag HD.

[10]. Cass, D., Williams, B., \& Barker, G. (Summer, 2004). China and the World Trading System: Entering the new millennium. Pacific Affairs, 77(2), 313-315.

[11]. Chen, C. (2009). WTO Accession, Foreign Direct Investment and International Trade (Advances in Chinese Economic Studies). Camberley, UK: Edward Elgar Publishing.

[12]. Ching, C. \& Ching, H. (2003). Handbook on China's WTO Accession and Its Impacts. Tuck Link, Singapore: World Scientific Publishing.

[13]. Cook, D. (Spring, 2015). Looking Beyond Accession: Challenges to implementing the World Trade Organization government procurement agreement in China. Journal of Public Procurement, 15(1), 93-116.

[14]. Dix-Carneiro, R. (May 2014). Trade Liberalization and Labor Market Dynamics. Econometrica: Journal of the Econometrica Society, 82(3), 825-885.

[15]. Fora, A. (2014). Annals of the University of Oradea, Economic Science Series, 23(1), 86-92.

[16]. Friedman, M. (1978). Free Trade: Producer versus consumer. Manhattan, KS: Kansas State University Press.

[17]. Hoadley, S. \& Yang, J. (2007). China's Regional and Cross-Regional FTA Overtures: In search for comprehensive national power. Pacific Affairs, 80(2), 327-48.

[18]. Huerta-Goldman, J. (February, 2010). Mexico in the WTO and NAFTA in a Nutshell: Litigating international trade disputes. Journal of World Trade, 44(1), 173-202.

[19]. Irwin, D. (2015). Free Trade under Fire. Princeton, NJ: Princeton University Press.

[20]. Kim, S. (2010). Power and the Governance of Global Trade: From the GATT to the WTO. Ithaca, NY: Cornell University Press.

[21]. Krugman, P. (1997). Pop Internationalism. Cambridge, Mass: The MIT Press.

[22]. Liu, J. (August, 2014). Accession Protocols: Legal status in the WTO legal system. Journal of World Trade, $48(4)$

[23]. 751-771.

[24]. McGovern, E. (2015). EU Anti-Dumping and Trade Defense Law and Practice. Topsham, UK: Globefield Press.

[25]. Michalopoulos, C. (1998). WTO Accession for Countries in Transition, World Bank, Development Research Group.

[26]. Issue 1934.

[27]. Mountjoy, A. (2007). Industrialization and Underdeveloped Countries Paperback. Rutgers University, New Jersey: Aldine Transaction Publishing.

[28]. Narlikar, A., Daunton, M., \& Stern, R. (2012). The Oxford Handbook on the World Trade Organization (Oxford Handbooks in Politics \& International Relations). New York, NY: Oxford University Press.

[29]. Nayyar, D. (2013). Catch Up: Developing countries in the world economy. New York, NY: Oxford University Press.

[30]. Neumayer, E. (October 2013). Strategic delaying and concessions extraction in accession negotiations to the World Trade Organization: An analysis of working party membership. World Trade Review, 12(4), 669-692.

[31]. PREM Advisory Service. (2015). Chapter 5. Economic Growth in the 1990s: Learning from a Decade of Reform. The World Bank Group.

[32]. Raslan, R. (2009). Antidumping: A developing country perspective. Alphen aan den Rijn, Netherlands: Kluwer Law International Publishing.

[33]. Rose, A. (March, 2004). Do We Really Know That the WTO Increases Trade? The American Economic Review, 94(1), 98-114. 
[34]. The International Economics Study Center. (1998). Chapter 5 WTO Accession. Washington, DC: George Washington University.

[35]. Tosevska, K. (2010). Regional vs. Multilateral, Bilateral vs. Regional Choices in the International Trade for the Republic of Macedonia. Conference Proceedings: International conference of the faculty of economics. Sarajevo (ICES), 1-11.

[36]. United Nations. (2015). United Nations Statistics Division. Retrieved from unstats.un.org/

[37]. Williams, P. \& Hussain, A. (2008). A Handbook on Accession to the WTO. Waterloo, ON: Cambridge University Press.

[38]. World Bank. (2005). Trade Liberalization: Why So Much Controversy? Chapter 5. Retrieved from http://www1.worldbank.org/prem/lessons1990s/chaps/05-ch05_kl.pdf.

[39]. World Trade Organization Development and Economic Research Division. (April, 2002) . Effects of WTO Accession on Policy-Making in Sovereign States: Preliminary lessons from the recent experience of transition countries. Staff Working Paper DERD-2002-02.

[40]. World Trade Organization, (2015). Regional Trade Agreements: Facts and Figures. How many regional trade agreements have been notified to the WTO?

[41]. World Trade Organization. (2015). Understanding the WTO: The Organization- Members and Observers. Wu, X., Liu, X., \& Du, J. (September, 2007). Local Firm's Knowledge Acquisition in the Global Manufacturing Network:

[42]. Evidence from Chinese samples. International Journal of Innovation \& Technology Management, 4(3), $267-281$.

[43]. Zhang, Y., Zhang, G., \& Zhang, H.G. (March/April, 2007). Chinese Economy, 40(2), 5-35.

[44]. Zhao, C., Lin, S., \& Bao, S. (2012). The Chinese Economy after WTO Accession . Farnham, Surrey, United Kingdom: Ashgate Publishing Company.

Appendix A: UN Stats GDP breakdown, categories

\begin{tabular}{|c|}
\hline Indicator Name \\
\hline Final consumption expenditure \\
\hline Household consumption expenditure (including Non-profit institutions serving households) \\
\hline Gross capital formation \\
\hline Gross fixed capital formation (including Acquisitions less disposals of valuables) \\
\hline Exports of goods and services \\
\hline Imports of goods and services \\
\hline Gross Domestic Product (GDP) \\
\hline Agriculture, hunting, forestry, fishing (ISIC A-B) \\
\hline Mining, Manufacturing, Utilities (ISIC C-E) \\
\hline Manufacturing (ISIC D) \\
\hline Construction (ISIC F) \\
\hline Wholesale, retail trade, restaurants and hotels (ISIC G-H) \\
\hline Transport, storage and communication (ISIC I) \\
\hline Other Activities (ISIC J-P) \\
\hline Total Value Added \\
\hline
\end{tabular}

